This item was submitted to Loughborough's Research Repository by the author.

Items in Figshare are protected by copyright, with all rights reserved, unless otherwise indicated.

\title{
Effect of a high and low dose of caffeine on human lymphocyte activation in response to antigen stimulation
}

PLEASE CITE THE PUBLISHED VERSION

http://dx.doi.org/10.1139/apnm-2015-0456

PUBLISHER

NRC Research Press

VERSION

AM (Accepted Manuscript)

\section{PUBLISHER STATEMENT}

This work is made available according to the conditions of the Creative Commons Attribution-NonCommercialNoDerivatives 4.0 International (CC BY-NC-ND 4.0) licence. Full details of this licence are available at: https://creativecommons.org/licenses/by-nc-nd/4.0/

\section{LICENCE}

CC BY-NC-ND 4.0

\section{REPOSITORY RECORD}

Dulson, Deborah K., and Nicolette Bishop. 2019. "Effect of a High and Low Dose of Caffeine on Human Lymphocyte Activation in Response to Antigen Stimulation”. figshare. https://hdl.handle.net/2134/20506. 
1 Effect of a high and low dose of caffeine on human lymphocyte activation in response to

2 antigen stimulation

3

4 Deborah K Dulson ${ }^{1}$ and Nicolette C Bishop ${ }^{2}$

5

6

${ }^{1}$ AUT University, Sports Performance Research Institute New Zealand, Auckland, New Zealand

$7{ }^{2}$ School of Sport, Exercise and Health Sciences, Loughborough University, Loughborough,

$8 \quad$ Leicestershire, UK. E-mail: N.C.Bishop@Iboro.ac.uk

9

10 Address for correspondence:

11

Deborah K Dulson

12

AUT University

13

SPRINZ

14

Private Bag 92006

Auckland 1020

New Zealand

17

Email: deborah.dulson@aut.ac.nz

19

Tel: +64 99219999 Ext 7417

20

Fax: +64992199999960

21

22 All authors declare that there are no conflicts of interest 
1

2

3

4

5

6

7

8

9

10

11

12

13

14

15

16

17

18

19

20

21

22

\section{Abstract}

This study investigated the effect of caffeine on antigen-stimulated lymphocyte activation. 6 males rested for $3.5 \mathrm{~h}$ after ingesting $0(\mathrm{PLA}), 2(2 \mathrm{CAF})$ or $6(6 \mathrm{CAF}) \mathrm{mg} \cdot \mathrm{kg}^{-1}$ body mass of

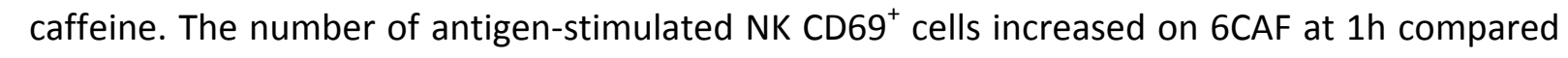
with placebo $(P=0.021)$. Caffeine did not influence the number of antigen-stimulated $C D 69^{+} \mathrm{T}$ cells or the GMFI expression of CD69 on antigen-stimulated lymphocytes, suggesting caffeine has little effect on antigen-stimulated lymphocyte activation.

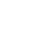

Keywords: Caffeine, methylxanthine, immune, CD69, lymphocytes, T cell, NK cell.

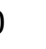




\section{Introduction}

Caffeine is a legal and socially acceptable drug and as such is commonly found in most people's diets. Caffeine's effects have been determined in a number of physiological systems including the cardiovascular, endocrine and central nervous systems (reviewed by Benowitz 1990). However, little research has focused on how caffeine may affect various aspects of the immune system (reviewed by Horrigan et al. 2006). Of the research that has been conducted, most have used the rodent model and very few studies have used concentrations of caffeine considered relevant to "normal" human consumption ( 70 $\mu \mathrm{M}$ or less; Graham 2001). Even fewer have used human participants (reviewed by Horrigan et al. 2006; Schiedel et al. 2013). It should also be taken into account that there are significant differences in caffeine metabolism and the plasma half-life of caffeine (rodents: 0.7-1.2 $\mathrm{h}$ vs. humans: $4-6 \mathrm{~h}$ ) between rodents and humans that may in fact limit extrapolation of findings from non-human models.

At rest (unstimulated), small numbers of peripheral blood lymphocytes express low levels of CD69 (Borrego et al. 1999; Testi et al. 1994). CD69 is one of the earliest cell surface glycoproteins expressed on lymphocytes following activation (Ziegler et al. 1994). Although the precise role of CD69 has not as yet been elucidated, many in vitro studies have demonstrated that once expressed on lymphocytes, this antigen appears to be involved in triggering subsequent cell proliferation, cytotoxicity and secretion of cytokines; such as tumour necrosis factor- $\alpha$ and interferon- $\gamma$ via its proposed actions as a co-stimulatory receptor (Borrego et al. 1999; Moretta et al. 1991; Mueller et al. 2002; Ziegler et al. 1994). 
1 Caffeine is a non-selective adenosine receptor antagonist and stimulates adrenaline release

2 from the adrenal medulla. T and NK cells express both $\beta_{2}$-adrenoreceptors and adenosine

3 receptors ( $T$ cells, $A_{2 A}, A_{2 B}$ and $A_{3} ;$ NK cells, $A_{1}, A_{2 A}$ and $A_{2 B}$ ), with the density of these receptors

4 increased following activation (Blay and Hoskin 2007; Shephard 2003). Both adenosine and

5 adrenaline have been shown to inhibit early lymphocyte activation (Lappas et al. 2005;

6 Shimamiya et al. 2003), via activation of adenylate cyclase and increased intracellular cAMP

7 (Raskovalova et al. 2006). Therefore, caffeine may have the potential to modulate lymphocyte

8 activation either directly via adenosine receptor antagonism or indirectly via stimulation of

9 catecholamine release.

To the authors knowledge no study to date has investigated the effect of caffeine on human lymphocyte activation in response to antigenic stimulation. Therefore, the aim of this study was to investigate the effect of a high and low dose of caffeine on antigen-stimulated lymphocyte $\left(\mathrm{CD}^{+}, \mathrm{CD}^{+}\right.$and $\left.\mathrm{CD}^{-} \mathrm{CD} 56^{+}\right)$activation over a period of $3.5 \mathrm{~h}$, as assessed by expression of CD69.

\section{Materials and methods}

Participants and trial protocol

Six healthy recreationally active participants [age 25 (2) years; weight 75 (7) kg] gave written informed consent to take part in the study, which was approved by the local Ethical Advisory Committee. 
activity questionnaire during their initial visit to the laboratory to ascertain if they were suitable for the study. Any participants that were currently on medication or had reported symptoms of infection in the 4 weeks prior to the study were excluded. Participants' habitual caffeine consumption was also recorded at the beginning of each study using a caffeine consumption questionnaire to classify participants as low, moderate or high habitual caffeine users. On the day of each main trial, a subsequent health-screening questionnaire was administered to confirm that participants were not experiencing any symptoms of URTI and were happy to take part in the study. Daily caffeine intake amongst participants was varied and ranged from $40-$ $220 \mathrm{mg} \cdot \mathrm{day}^{-1}$, with an average intake of $120 \pm 85 \mathrm{mg} \cdot \mathrm{day}^{-1}$. Two subjects were characterised as as light users $\left(<50 \mathrm{mg}\right.$. day $\left.^{-1}\right)$ and the other 4 as moderate users $\left(50-250 \mathrm{mg}\right.$. day $\left.{ }^{-1}\right)$.

To standardize nutritional status, participants completed a $24 \mathrm{~h}$ food diary the day before the first main trial and were asked to follow this during the $24 \mathrm{~h}$ preceding the second and third main trial. Participants were randomly assigned to either the placebo (PLA), low caffeine dose (2CAF) or high caffeine dose (6CAF) trial and acted as their own controls in a repeatedrepeated-measures, single-blind, cross-over design. Each trial was separated by 1 week. Participants arrived at the laboratory at 08:20 h following an overnight fast of $12 \mathrm{~h}$ and $60 \mathrm{~h}$ abstention from caffeine. After 10 min of resting quietly an initial $(0 \mathrm{~h})$ blood sample was obtained from an antecubital forearm vein by venepuncture. Following the blood sample, participants ingested 0,2 or $6 \mathrm{mg} \cdot \mathrm{kg}^{-1}$ body mass of caffeine powder (BDH Laboratory Supplies, Poole, UK) taken in the form of cellulose capsules (G \& G Food Supplies Ltd, West Sussex, UK) with $300 \mathrm{ml}$ plain water. For the PLA trial, participants ingested $6 \mathrm{mg} \cdot \mathrm{kg}^{-1}$ body mass of 
dextrose powder (BDH Laboratory Supplies, Poole, UK). Participants then rested quietly in the the laboratory for $3.5 \mathrm{~h}$, during which time water was consumed ad libitum. Further blood samples were taken after $1 \mathrm{~h}(09: 30 \mathrm{~h}), 2.5 \mathrm{~h}(11: 00 \mathrm{~h})$ and $3.5 \mathrm{~h}(12: 00 \mathrm{~h})$.

\section{Lymphocyte culture and flow cytometry}

Five $\mathrm{ml}$ of whole blood containing sodium heparin was immediately placed on ice after draw and mixed for 20 min before setting up cultures and performing flow cytometry, as previously described (Fletcher and Bishop 2012).

\section{Serum caffeine and plasma adrenaline}

Whole blood collected into a plain monovette $(5.5 \mathrm{ml})$ was left to clot for $1 \mathrm{~h}$ before centrifuged at $1500 \mathrm{~g}$ for $10 \mathrm{~min}$ at $4^{\circ} \mathrm{C}$. Heparinized plasma was obtained from blood collected into a lithium heparin monovette $(7.5 \mathrm{ml})$. Samples were spun at $1500 \mathrm{~g}$ for $10 \mathrm{~min}$ at $4^{\circ} \mathrm{C}$ within 5 min of collection. Serum caffeine and plasma adrenaline concentration were measured as previously described (Fletcher and Bishop 2012).

\section{Statistical analysis}

The data were examined using a two-factor (trial $x$ time) analysis of variance with repeated measures design. If the data were not normally distributed, statistical analysis was carried out on the logarithmic transformation of the data. Assumptions of sphericity in the data were checked, and adjustments in the degrees of freedom for the ANOVA were made using the Huynh-Feldt method of correction where appropriate. Any significant data were assessed using 
using Student's paired $t$-tests with Holm-Bonferroni adjustments for multiple comparisons. Statistical significance for this study was accepted at $P<0.05$. The observed powers of the reported main and interaction effects are all $>0.8$.

Results

Serum caffeine concentration at $1 \mathrm{~h}, 2.5 \mathrm{~h}$ and $3.5 \mathrm{~h}$ after caffeine ingestion was higher on 6CAF than 2CAF and PLA and higher on 2CAF than PLA ( $F=24.058$, all $P=0.000$; Table 1$)$. At $1 \mathrm{~h}$ and 2.5 $\mathrm{h}$ after caffeine ingestion, plasma adrenaline concentration was higher on 6CAF than PLA $(\mathrm{F}=9.273,1 \mathrm{~h}, \mathrm{P}=0.038 ; 2.5 \mathrm{~h} \mathrm{P}=0.003 ;$ Table 1$)$. Neither caffeine ingestion nor time of day affected the number of $\mathrm{CD}^{+}$and $\mathrm{CD} 8^{+}$cells within the circulating lymphocyte population (Table 1). However, the number of $\mathrm{CD}^{-} \mathrm{CD}^{-} 6^{+}$cells was higher $1 \mathrm{~h}$ and $2.5 \mathrm{~h}$ after caffeine ingestion on 6CAF than on PLA and 2CAF (F=5.806, $1 \mathrm{~h}: 6 \mathrm{CAF} \vee \mathrm{PLA} P=0.002,6 \mathrm{CAF} \vee 2 \mathrm{CAF} P=0.042 ; 2.5 \mathrm{~h}$ : $6 C A F \vee P L A P=0.046,6 C A F \vee 2 C A F P=0.036 ;$ Table 1). There was no effect of caffeine on the number of unstimulated $\mathrm{CD}^{+}, \mathrm{CD}^{+}$and $\mathrm{CD}^{-} \mathrm{CD}^{-} 6^{+}$cells or antigen-stimulated (both doses) $\mathrm{CD}^{+}$and $\mathrm{CD} 8^{+}$cells expressing CD69 (unstimulated, data in Supplementary Table 1; antigenstimulated, Table 2). A high dose of caffeine increased the number of antigen-stimulated $\mathrm{CD}^{-}$ $\mathrm{CD}^{+} 6^{+}$cells expressing CD69 $1 \mathrm{~h}$ following caffeine ingestion compared with PLA (6CAF 1:4000 v PLA 1:4000, F=2.536, P=0.021; Fig. 1). Neither caffeine ingestion nor time of day affected the geometric mean fluorescence intensity (GMFI) of CD69 expression on unstimulated (Supplementary Table 1) or antigen-stimulated $\mathrm{CD} 4^{+}, \mathrm{CD}^{+}$and $\mathrm{CD}^{-} \mathrm{CD}^{-} 6^{+}$cells (Table 3 ). 


\section{Discussion}

The main findings of this study suggest that (i) a high dose of caffeine increases the number of antigen-stimulated $\mathrm{CD}^{-} \mathrm{CD}^{2} 6^{+}$cells expressing $\mathrm{CD} 691 \mathrm{~h}$ following caffeine ingestion, (ii) ingesting high and low doses of caffeine has little influence on antigen-stimulated $\mathrm{T}\left(\mathrm{CD} 4^{+}\right.$and $\mathrm{CD}^{+}$) cell activation and (iii) caffeine ingestion has little effect on the density of CD69 expression on antigen-stimulated T and NK cells, as assessed by the GMFI expression of CD69.

In the present study both high and low doses of caffeine had little effect on the density of expression of the CD69 receptor on antigen-stimulated T and NK cells. This is in contrast to several reports that caffeine at physiological concentrations decreases other lymphocyte functions such as mitogen/antigen stimulated lymphocyte proliferation, antibody production and cytokine production (Kantamala et al. 1990; Rosenthal et al. 1992). However, these studies studies used rodent models to investigate the possible effects of caffeine. Although the present study in humans and the previous studies in rodents have not used exactly the same measures of lymphocyte function, there is good evidence to suggest that CD69 expression is a reliable measure of subsequent T cell proliferation and NK cell cytotoxicity in vitro (Green et al. 2003; McFarlin et al. 2004). Recently Schiedel et al. (2013) investigated the effects of caffeine on both unstimulated and mitogen-stimulated human lymphocyte proliferation. These reserachers found that caffeine at physiologically relevant concentrations $(0.1-30 \mu \mathrm{M})$ had no effect on unstimulated or PHA-stimulated lymphocyte proliferation. The contrasting findings between human and rodent studies itself raises issues of validity when comparing results, as caffeine metabolism and plasma half-life between rodents and humans differs significantly 
(Fredholm et al. 1999).

At physiological concentrations, it is thought that caffeine's main mechanism of action is via adenosine receptor antagonism (Fredholm et al. 1999). However, under physiological conditions, caffeine will only actively compete as an adenosine receptor antagonist when the receptors are engaged by endogenous adenosine (Yang et al. 2009). As such, it could be suggested that in the present study caffeine (regardless of dose) had little effect on antigenstimulated lymphocyte activation (GMFI expression of CD69) in resting participants due to plasma adenosine concentrations being too low to engage caffeine as an adenosine receptor antagonist. It should be noted that plasma adenosine was not measured in this study and as such this explanation is only speculation. However, support comes from the exercise literature where prolonged intensive exercise, which is known to markedly increase plasma adenosine (Vizi et al. 2002), increased the number of unstimulated $C D 4^{+}$and $C D 8^{+}$T cells expressing CD69 (Bishop et al. 2005). In contrast, plasma adrenaline concentration mirrored the effects of a high dose of caffeine on the number of NK cells expressing CD69 in response to antigen stimulation. Given adrenaline's known role in lymphocyte mobilization (Shephard 2003) this may suggest an adrenaline-mediated mobilization of this specific population of cells.

In summary, this is the first study in humans to determine that a high $\left(6 \mathrm{mg} \cdot \mathrm{kg}^{-1}\right)$ but not a low $\left(2 \mathrm{mg} \cdot \mathrm{kg}^{-1}\right)$ dose of caffeine increases the number of NK cells expressing the early activation marker CD69 in response to antigen stimulation $1 \mathrm{~h}$ following caffeine ingestion. This may be related to increases in adrenaline and subsequent mobilization of this specific population of 
cells. In contrast, caffeine ingestion (regardless of dose) has little effect on the density of the expression of CD69 on antigen-stimulated T and NK cells in humans. These findings are in contrast to previously published studies in the animal model and as such suggest that perhaps rodents are not a reliable model with which to investigate the effects of caffeine on human lymphocyte functions.

\section{Acknowledgments}

We would like to thank Karen Swift at the School of Biomedical Sciences, Queens Medical Centre, Nottingham for performing the HPLC analysis.

\section{References}

Benowitz, N.L. 1990. Clinical pharmacology of caffeine. Annu. Rev. Med. 41: 277-288.

Bishop, N.C., Fitzgerald, C., Porter, P.J., Scanlon, G.A., and Smith, A.C. 2005. Effect of caffeine ingestion on lymphocyte counts and subset activation in vivo following strenuous cycling. Eur. J. Appl. Physiol. 93 (5-6): 606-613.

Blay, J., Hoskin, D.W. 2007. Impaired lymphocyte activation in the presence of adenosine: mechanisms and physiological relevance. In Adenosine receptors: therapeutic aspects for inflammatory and immune diseases. Edited by G. Haskó, B.N. Cronstein and Szabó. CRC Press, London. pp. 69-88 
2 Borrego, F., Robertson, M.J., Ritz, J., Peña, J., and Solana, R. 1999. CD69 is a stimulatory 3 receptor for natural killer cell and its cytotoxic effect is blocked by CD94 inhibitory receptor. $4 \quad$ Immunology 97 (1): 159-165.

6 Fletcher, D.K., and Bishop, N.C. 2012. Caffeine ingestion and antigen-stimulated human 7 lymphocyte activation after prolonged cycling. Scand. J. Med. Sci. Sports 22 (2): 249-258.

8

Fredholm, B.B., Battig, K., Holmen, J., Nehlig, A., and Zvartau, E.E. 1999. Actions of caffeine in the brain with special reference to factors that contribute to its widespread use. Pharmacol. Rev. 51 (1): 83-133.

Graham, T.E. 2001. Caffeine and exercise: metabolism, endurance and performance. Sports Med. 31 (11): 785-807.

Green, K.J., Rowbottom, D.G., and Mackinnon, L.T. 2003. Acute exercise and T-lymphocyte expression of the early activation marker CD69. Med. Sci. Sports Exer. 35 (4): 582-588.

Horrigan, L.A., Kelly, J.P., and Connor, T.J. 2006. Immunomodulatory effects of caffeine: friend or foe? Pharmacol. Therapeut. 111 (3): 877-892.

Kantamala, D., Vongsakul, M., and Satayavivad, J. 1990. The in vivo and in vitro effects of 
caffeine on rat immune cells activities: B, T and NK cells. Asian Pac. J. Allergy Immunol. 8 (2): 77$77-82$.

Lappas, C.M., Rieger, J.M., and Linden, J. 2005. $A_{2 A}$ adenosine receptor induction inhibits IFN- $\gamma$ production in murine $\mathrm{CD}^{+}{ }^{+}$T cells. J. Immunol. 174 (2): 1073-1080.

McFarlin, B.K., Flynn, M.G., Stewart, L.K., and Timmerman, K.L. 2004. Carbohydrate intake during endurance exercise increases natural killer cell responsiveness to IL-2. J. Appl. Physiol. 96 (1): 271-275.

Moretta, A., Poggi, A., Pende, D., Tripodi, G., Orengo, A.M., Pella, N., et al. 1991. CD69mediated pathway of lymphocyte-activation: anti-CD69 monoclonal antibodies trigger the cytolytic activity of different lymphoid effector cells with the exception of cytolytic T lymphocytes expressing T cell receptor $\alpha / \beta$. J. Exp. Med. 174 (6): 1393-1398.

Mueller, S.N., Jones, C.M., Smith, C.M., Heath, W.R., and Carbone, F.R. 2002. Rapid cytotoxic T lymphocyte activation occurs in the draining lymph nodes after cutaneous herpes simplex virus infection as a result of early antigen presentation and not the presence of virus. J. Exp. Med. 195 (5): 651-656.

Raskovalova, T., Lokshin, A., Huang, X., Jackson, E.K., and Gorelik, E. 2006. Adenosine-mediated inhibition of cytotoxic activity and cytokine production by IL-2/NKp46-activated NK cells: 
involvement of protein kinase A isozyme I (PKA I). Immunol. Res. 36 (1-3): 91-100.

3

Rosenthal, L.A., Taub, D.D., Moors, M.A., and Blank, K.J. 1992. Methylxanthine-induced inhibition of the antigen- and superantigen-specific activaton of $T$ and $B$ lymphocytes. Immunopharmacol. 24 (3): 203-217.

Schiedel, A.C., Lacher, S.K., Linnemann, C., Knolle, P.A., and Müller, C.E. 2013. Antiproliferative effects of selective adenosine receptor agonists and antagonists on human lymphocytes: evidence for receptor-independent mechanisms. Purinergic Signal. 9 (3): 351-365

Shephard, R.J. 2003. Adhesion molecules, catecholamines and leucocyte redistribution during and following exercise. Sports Med. 33 (4): 261-284.

Shimamiya, T., Wakabayashi, S., and Terada, N. 2003. Effects of adrenaline and cortisone on the early activation of lymphocytes. Biol. Sci. Space 17 (3): 221-222.

Testi, R., D'Ambrosio, D., De Maria, R., and Santoni, A. 1994. The CD69 receptor: a multipurpose cell-surface trigger for hematopoietic cells. Immunol. Today 15 (10): 479-483.

Vizi, E., Huszar, E., Csoma, Z., Boszormenyi-Nagy, G., Barat, E., Horvath, I., et al. 2002. Plasma adenosine concentration increases during exercise: a possible contributing factor in exerciseinduced bronchoconstriction in asthma. J. Allergy Clin. Immunol. 109 (3): 446-448. 
2 Yang, J.N., Björklund, O., Lindström-Törnqvist, K., Lindgren, E., Eriksson, T.M., Kahlström, J., et 3 al. 2009. Mice heterozygous for both $A_{1}$ and $A_{2 A}$ adenosine receptor genes show similarities to 4 mice given long-term caffeine. J. Appl. Physiol. 106 (2): 631-639.

5

Ziegler, S.F., Ramsdell, F., and Alderson, M.R. 1994. The activation antigen CD69. Stem Cells 12 (5): 456-465.

.

1

12

13


Table 1: Serum caffeine, plasma adrenaline concentrations, total lymphocyte count and number of circulating $\mathrm{CD}^{+}, \mathrm{CD}^{+}$and $\mathrm{CD}^{-} \mathrm{CD}^{-} 6^{+}$cells during PLA, 2CAF and $6 \mathrm{CAF}$ trials.

\begin{tabular}{|c|c|c|c|c|c|}
\hline & $\mathbf{O h}$ & $1 \mathrm{~h}$ & $2.5 \mathrm{~h}$ & $3.5 \mathrm{~h}$ & \\
\hline \multicolumn{6}{|c|}{ Serum caffeine concentration $\left(\mu \mathrm{mol} \cdot \mathrm{L}^{-1}\right)$} \\
\hline PLA & $0(0)$ & & $0(0)$ & $0(0)$ & $0(0)$ \\
\hline 2CAF & $0(0)$ & & $16(8) * \ddagger$ & $17(3) * \ddagger$ & $15(3) * \ddagger$ \\
\hline $6 \mathrm{CAF}$ & $0(0)$ & & $48(11) \dagger \ddagger$ & $47(11) \dagger \ddagger$ & $43(9) \dagger \ddagger$ \\
\hline \multicolumn{6}{|c|}{ Plasma adrenaline concentration $\left(\mathrm{nmol} \cdot \mathrm{L}^{-1}\right)$} \\
\hline PLA & $0.10(0.04)$ & & $0.09(0.05)$ & $0.11(0.07)$ & - \\
\hline 2CAF & $0.13(0.07)$ & & $0.12(0.05)$ & $0.18(0.08)$ & - \\
\hline $6 \mathrm{CAF}$ & $0.08(0.06)$ & & $0.15(0.07) * * \ddagger \ddagger$ & $0.26(0.10) * \ddagger$ & - \\
\hline \multicolumn{6}{|c|}{ Total lymphocytes $\left(\times 10^{9}\right.$ cells $\left.\cdot \mathrm{L}^{-1}\right)$} \\
\hline PLA & $1.90(0.30)$ & & $1.70(0.10)$ & $1.80(0.20)$ & $1.80(0.30)$ \\
\hline 2CAF & $1.80(0.40)$ & & $1.60(0.40)$ & $1.70(0.30)$ & $1.80(0.03)$ \\
\hline $6 \mathrm{CAF}$ & $1.90(0.30)$ & & $2.00(0.30)$ & $2.00(0.30)$ & $1.80(0.10)$ \\
\hline \multicolumn{6}{|c|}{$\mathrm{CD4}^{+}$cells $\left(\times 10^{9}\right.$ cells $\left.\cdot \mathrm{L}^{-1}\right)$} \\
\hline PLA & $0.77(0.23)$ & & $0.70(0.11)$ & $0.68(0.13)$ & $0.67(0.11)$ \\
\hline 2CAF & $0.66(0.19)$ & & $0.62(0.16)$ & $0.62(0.15)$ & $0.71(0.14)$ \\
\hline $6 \mathrm{CAF}$ & $0.66(0.15)$ & & $0.62(0.13)$ & $0.58(0.19)$ & $0.64(0.08)$ \\
\hline \multicolumn{6}{|c|}{$\mathrm{CD}^{+}$cells $\left(\times 10^{9}\right.$ cells $\left.\cdot \mathrm{L}^{-1}\right)$} \\
\hline PLA & $0.58(0.10)$ & & $0.50(0.09)$ & $0.51(0.09)$ & $0.52(0.13)$ \\
\hline 2CAF & $0.54(0.13)$ & & $0.50(0.14)$ & $0.50(0.11)$ & $0.54(0.10)$ \\
\hline $6 \mathrm{CAF}$ & $0.50(0.10)$ & & $0.60(0.25)$ & $0.50(0.23)$ & $0.49(0.13)$ \\
\hline \multicolumn{6}{|c|}{$\mathrm{CD}^{-} \mathrm{CD}^{-} 6^{+}$cells $\left(\times 10^{9}\right.$ cells $\left.\cdot \mathrm{L}^{-1}\right)$} \\
\hline PLA & $0.30(0.12)$ & & $0.22(0.07)$ & $0.28(0.11)$ & $0.30(0.16)$ \\
\hline $2 \mathrm{CAF}$ & $0.22(0.09)$ & & $0.21(0.07)$ & $0.20(0.10)$ & $0.30(0.13)$ \\
\hline $6 \mathrm{CAF}$ & $0.29(0.11)$ & & $0.41(0.17)+\dagger \ddagger$ & $0.37(0.07)+† \ddagger \ddagger$ & $0.30(0.06)$ \\
\hline
\end{tabular}

Values are mean (SD).

${ }^{*} P<0.01, * * P<0.05$ : Significantly higher than PLA

$+P<0.01,++P<0.05:$ Significantly higher than PLA and $2 \mathrm{CAF}$

$\ddagger P<0.01$, $\ddagger \ddagger P<0.05$ : Significantly higher than $0 \mathrm{~h}$ within trial 
1 Table 2: Number of antigen-stimulated $\mathrm{CD}^{+}, \mathrm{CD}^{+}$and $\mathrm{CD}^{-} \mathrm{CD}^{-} 6^{+}$cells expressing $\mathrm{CD} 69$ during 2 PLA, 2CAF and 6CAF trials.

\begin{tabular}{|c|c|c|c|c|}
\hline & $\mathbf{O h}$ & $2.5 \mathrm{~h}$ & $3.5 \mathrm{~h}$ & \\
\hline \multicolumn{5}{|c|}{$\mathrm{CD4}^{+} \mathrm{CD} 9^{+}$cells $\left(\times 10^{6}\right.$ cells $\left.\cdot \mathrm{L}^{-1} ; 1: 4000\right)$} \\
\hline PLA & $25(21)$ & $28(19)$ & $32(20)$ & $41(23)$ \\
\hline 2CAF & $25(15)$ & $30(15)$ & $43(30)$ & $44(30)$ \\
\hline $6 \mathrm{CAF}$ & $28(20)$ & $34(25)$ & $34(21)$ & $35(21)$ \\
\hline \multicolumn{5}{|c|}{ 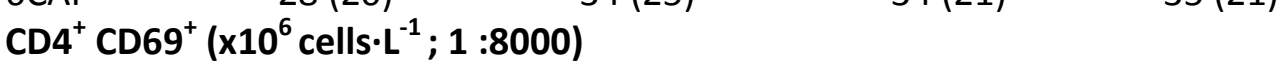 } \\
\hline PLA & $15(8)$ & $22(14)$ & $24(15)$ & $37(24)$ \\
\hline 2CAF & $19(10)$ & $20(13)$ & $34(21)$ & $40(31)$ \\
\hline $6 \mathrm{CAF}$ & $22(17)$ & $28(20)$ & $35(27)$ & $34(26)$ \\
\hline \multicolumn{5}{|c|}{$\mathrm{CD8}^{+} \mathrm{CD}^{+} 9^{+}\left(\times 10^{6}\right.$ cells $\left.\cdot \mathrm{L}^{-1} ; 1: 4000\right)$} \\
\hline PLA & $45(37)$ & $33(20)$ & $45(24)$ & $50(27)$ \\
\hline 2CAF & $26(18)$ & $32(20)$ & $38(23)$ & $45(26)$ \\
\hline $6 \mathrm{CAF}$ & $29(17)$ & $50(42)$ & $41(26)$ & $37(23)$ \\
\hline \multicolumn{5}{|c|}{$\mathrm{CD}^{+} \mathrm{CD}^{+} 9^{+}\left(\times 10^{6}\right.$ cells $\left.\cdot \mathrm{L}^{-1} ; 1: 8000\right)$} \\
\hline PLA & $28(16)$ & $30(19)$ & $34(25)$ & $52(33)$ \\
\hline 2CAF & $19(14)$ & $24(14)$ & $31(20)$ & 41 (29) \\
\hline $6 \mathrm{CAF}$ & $23(15)$ & $40(35)$ & $44(37)$ & $36(28)$ \\
\hline \multicolumn{5}{|c|}{$\mathrm{CD}^{-} \mathrm{CD}^{2} 6^{+} \mathrm{CD} 9^{+}\left(\times 10^{6}\right.$ cells $\left.\cdot \mathrm{L}^{-1} ; 1: 8000\right)$} \\
\hline PLA & $39(25)$ & $42(35)$ & $43(22)$ & $57(33)$ \\
\hline 2CAF & $33(29)$ & $30(23)$ & $30(29)$ & $62(60)$ \\
\hline $6 \mathrm{CAF}$ & $51(61)$ & $47(29)$ & $61(43) \ddagger \ddagger$ & $55(21)$ \\
\hline
\end{tabular}

Values are mean (SD).

$\ddagger \ddagger P<0.05$ : Significantly higher than $0 \mathrm{~h}$ within trial 
1 Table 3: GMFl expression of $\mathrm{CD} 69$ on antigen-stimulated $\mathrm{CD} 4^{+}, \mathrm{CD}^{+}$and $\mathrm{CD} 3^{-} \mathrm{CD} 56^{+}$cells during 2 PLA, 2CAF and 6CAF trials.

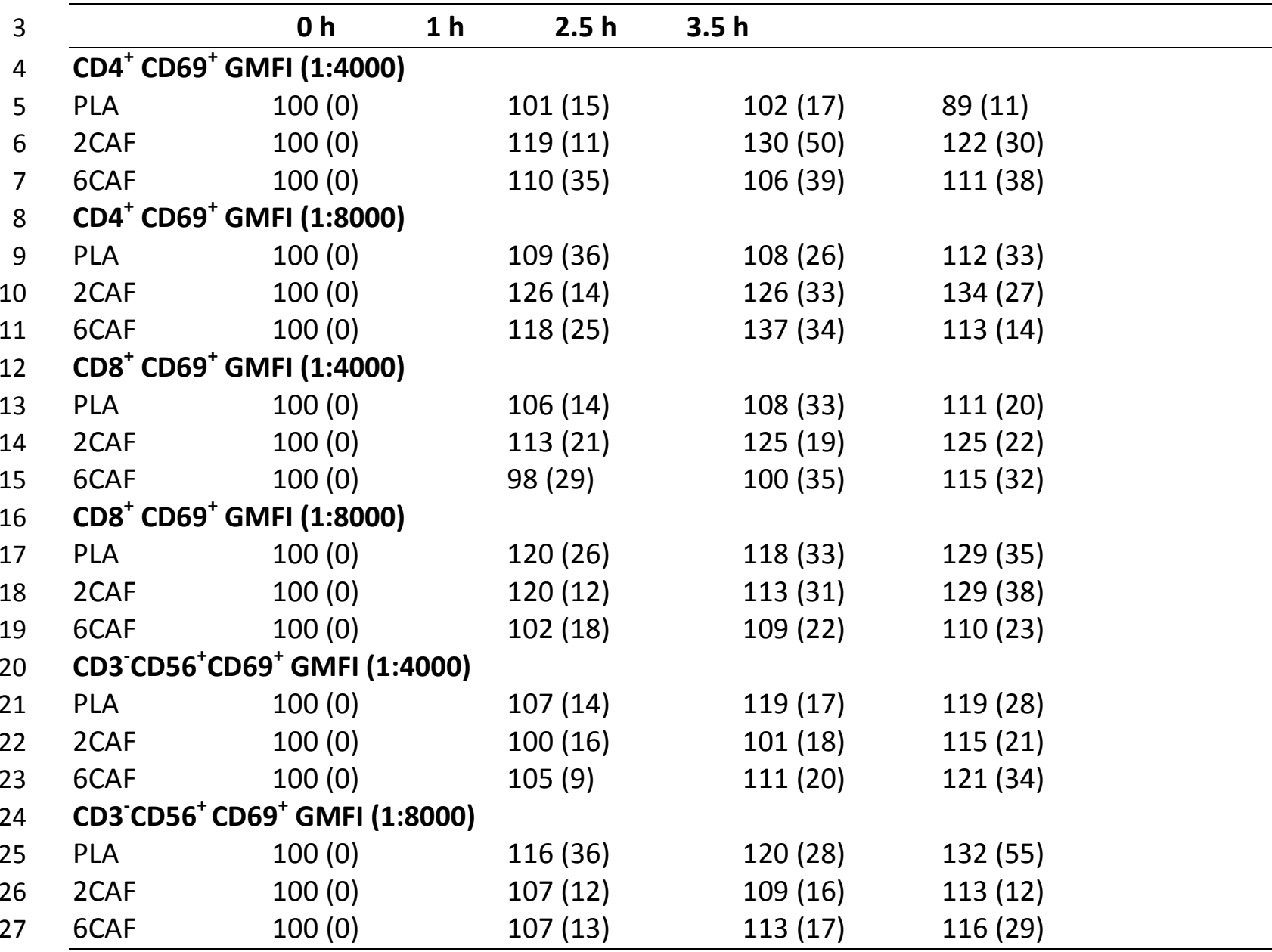
Values are mean (SD). The GMFI expressions are expressed as a percentage relative to the $0 \mathrm{~h}$ value. 


\section{Figure Caption}

2 Fig. 1. Number of antigen-stimulated (1:4000) $\mathrm{CD}^{-} \mathrm{CD} 56^{+} \mathrm{NK}$ cells expressing $\mathrm{CD} 69$ within the

3 circulating lymphocyte population during PLA, 2CAF and 6CAF trials. * significantly higher on

46 CAF than PLA, $\mathrm{P}=0.021 ;+$ significantly higher than $0 \mathrm{~h}$ within trial $(\mathrm{P}<0.05)$. Values are means + 5 SD. 


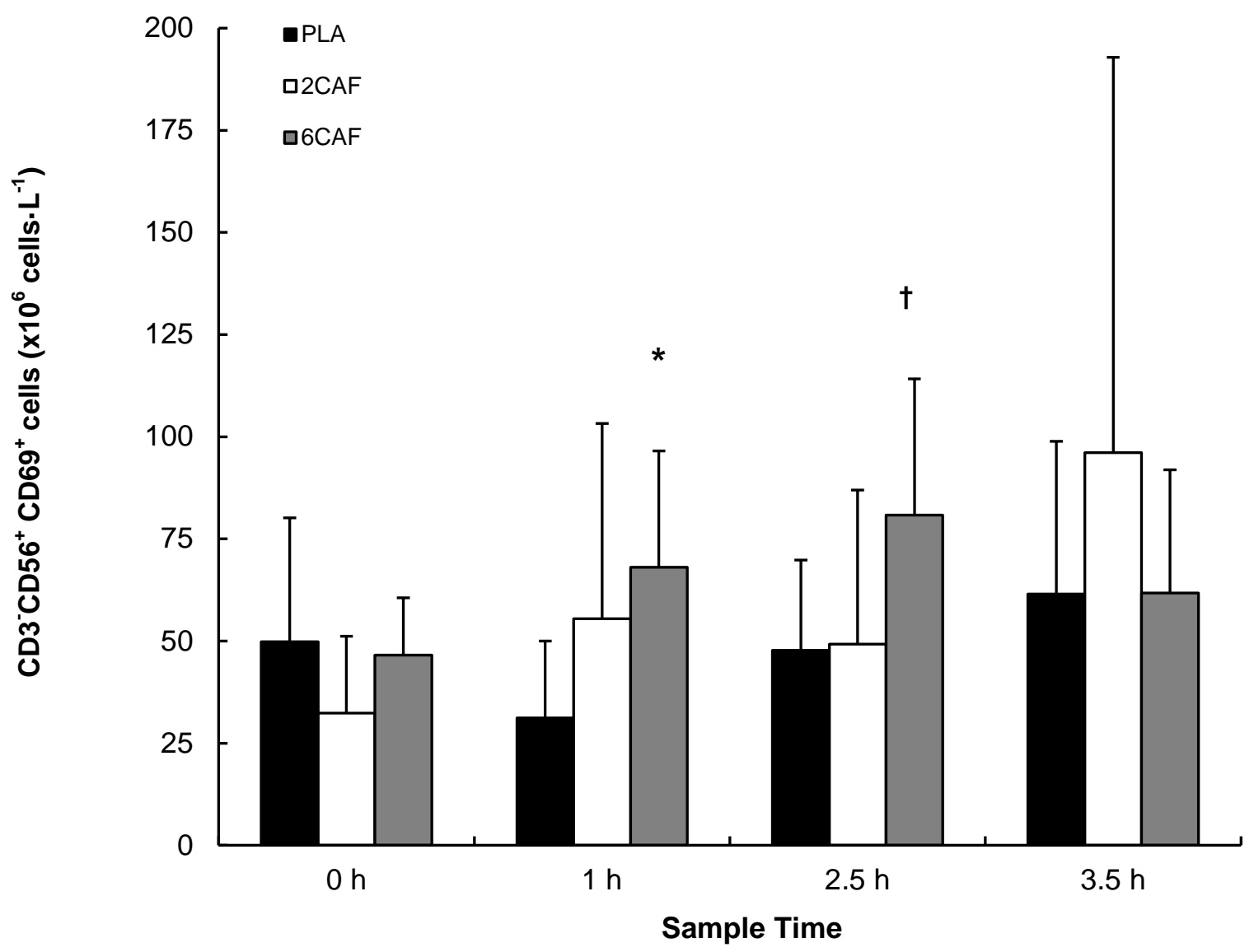

